Regular Research Article

\title{
From SEZs to Thailand 4.0: Geopolitics of Borderlands in the Thai State's Vision
}

\author{
Phianphachong Intarat ${ }^{1, *}$ \\ 1 Ph.D. Student in Anthropology, University of Hawai'i at Mānoa. \\ * Correspondence author: pintarat@hawaii.edu
}

\begin{abstract}
This article uses the case of Thailand's two economic policies -the border Special Economic Zones and the Thailand 4.0 model, to explore geopolitics of the Thai-Burmese borderland. It also discuss a theoretical gap in accounting the ways in which the state engages with transnational flows of capital and peoples, and proposes to use the concept of 'border partial citizenship' to bridge this gap. It argues that the shift in Thailand's economic policy portrayed the different ways in which the Thai state envisaged its geographical territory in relations to capital and human mobility. In the border SEZ project, the Thai borderland is a site where the state loosened its relationship with its non-subjects. However, while the border regions seem increasingly opening for migrant mobility, the inner core of the Thai geo-body, a geographical territory that embodies nationhood, is proportionately hyper-sanitized by patriotic discourses of the national advancement in knowledge-based economy and the harsh policy toward undocumented migrant population.
\end{abstract}

Keywords: special economic zone (SEZ); border partial citizenship; labor migration policy; Thailand; geopolitics

\section{Introduction}

After assuming power in May 2014, the military government led by General Prayut Chan-o-cha pushed forward the plan to establish special economic zones (SEZs) along the country's borders. During this time, the idea about SEZs was situated in the context of the ASEAN Economic Community $(A E C)$, a regional economic integration that promotes connectivity between the member countries of ASEAN. The incumbent government under General Chan-o-cha declared the first phase of border SEZ pilot projects in six provinces neighboring Myanmar ${ }^{1}$, Lao PDR, Cambodia, and Malaysia. A scalar move with the nearly unchecked power of the military government created an ephemeral euphoria among the Thai public given the speculation of economic benefits from the plan. The policy implementation, however, later encountered resistance from local entities and the plan to materialize SEZs has become sluggish. In December 2016, Thailand 4.0, a new economic model was introduced to the Thai public attention. The government made a bolder claim to transform Thailand into an unprecedented high-valued and technology-based economy. The narrative about crossborder connectivity was replaced with an inward-looking development theme infused with new buzz words such as innovation, technology research, and sustainable development, etc.

\footnotetext{
${ }^{1}$ A word choice for this country's official name has been politicized. Some scholars and civil society groups prefer 'Burma' over 'Myanmar' as the latter is a brainchild of the Burmese junta government in 1989. On the other hand, the oppose argue, the term 'Burma' is a colonialist name given to the country by the British colonizers in the late nineteenth century. However, in Burmese language, both terms do exist, yet in different registers. While 'bama' is more common in colloquial language, 'myanma' usually appears in literary style. Following this linguistic tradition, in this article I therefore use the term 'Myanmar' to refer to the country while using 'Burmese' to describe peoples from Myanmar that are not limited to the Burman ethnic majority, but also includes other ethnicities such as the Karen, the Mon, and the Arakanese.
} 
Beyond the surface of this seemingly mundane political uncertainty under the military regime, this paper explores a geopolitical aspect of this economic policy shift within a center-periphery framework. Focusing on the Thai government's positioning of borderlands in its changing economic vision, I ask: how does the rise and fall of the border SEZs in the Thai national economic agenda articulate geopolitics of borderlands? What does this policy change tell us about ways in which the state copes with tension between benefiting from global flows of capital and securitizing its territory from unauthorized human mobility? Ultimately, how is the Thai geo-body, concisely posited here as a spatial conception of nationhood (Winichakul, 1994), envisaged through the state's development plan? I argue that in the border SEZs project, the Thai borderlands are projected as part of a larger regional connectivity and a site where a form of the Thai state's reterritorialization takes place. In this process, the Thai state reorganized its relationship to flow of migrant workers within its national territory, through the enforcement of Article 14 of the Alien Employment Act B.E.2551 (2008). In doing so, the Thai state turns the border SEZs into an 'economic dam' ${ }^{2}$ where its desire for transnational flow of capital is reconciled with its ambivalence toward flow of migrant workers from neighboring countries. However, while the border regions seem increasingly opening for migrant mobility, the inner core of the Thai geo-body is proportionately hyper-sanitized by patriotic discourses of the national advancement in knowledge-based economy and the harsh policy toward undocumented migrant population.

In what follows, I first explain the research methodology. Then, I provide a brief background summary of SEZs in Southeast Asia. In Section Four, I discuss Thailand's economic development in the regional context, and articulate tension between free flow of capital and human mobility in the form of labor immigration. In Section Five, I outline a theoretical gap in studying the Thai border SEZs and propose a framework to account for the peculiarity of the case. In Section Six to Eight I provide an analysis of geopolitical implications of the two economic plans, to which the ThaiBurmese borderland is integral. In the analysis, I demonstrate the way in which the Thai state articulates its vision of the Thai geo-body through the positioning of borderlands in its different economic discourses. This macro analysis of policy change is interlaced with an ethnography of Burmese migrant workers who encountered the manifestation of the Thai state's vision firsthand in the Thai-Burmese border areas.

\section{Methodology}

In this article, I employ an interdisciplinary approach to create an analysis of Thailand's rapidly changing socio-economic and political landscapes and the way in which these changes impact people on the ground, especially the marginalized group like migrant workers in the border areas. Documentary research is the main method for this article. In order to answer the research questions mentioned above, I collected and analyzed a variety of relevant resources such as Thai laws on labor migration and immigration control, the Thai government's press releases, and various kinds of media and newspapers. The data analysis in this documentary research is substantiated with the ethnographic data gained from my fieldwork in migrant communities in the Thai-Burmese border area where a border SEZ is located.

As for the ethnographic part, the main research site is Mae Sot, a Thai most western border boomtown across Myawaddy, Myanmar. I had an opportunity to conduct fieldwork in Mae Sot in three visits during 2014-2017. These visits lasted six, three, and two months, respectively, with a gap year in 2016. ${ }^{3}$ During my fieldworks, I worked with three field research assistants whose first

\footnotetext{
2 It is not my intention to claim the originality for the idea of border SEZs as an economic dam as the idea has been discussed by many scholars. However, my point here is to demonstrate that the idea of the 'economic dam' is formalized with the enforcement of Article 14 of the Alien Employment Act B.E.2551. 3 The first two fieldworks in 2014 and 2015 were part of a research project entitled "Mae Sot SEZ: Implications of Global/Regional Integration on Workers, State, and Region." This project was led by Dr. Decha Tangseefa (Thammasat University) and funded by the Thailand Research Fund (TRF). I am always grateful for the exemplary mentorship and generosity of Dr. Decha Tangseefa, who not only guided me through this incredibly complexed field, but also allowed me to use some of the data from this project for my independent study including this article. The third fieldwork in 2017 was funded by the Henry Luce Foundation Hawai'i-Wisconsin Faculty/student Collaborative Research Fellowship, in which I am also grateful
} 
language was Burmese and they were fluent in English and/or Thai. ${ }^{4}$ Each assistant helped me translating the interviews with migrant workers and cross-border civil society personnel who were not comfortable speaking in Thai and English. Although the assistants' familiarity to the migrant communities in Mae Sot and its vicinity, often helped facilitate the research activities a great deal, the two-fold translation was indeed challenging. Hence, throughout the three phases of field research, the assistants and I spent much more time than we had expected cross-checking and validating data from the interviews and participant observation in the communities to lessen this linguistic gap as much as we could. This effort was to ensure that our claim for an emic view about migrant lives in the Thai-Burmese borderlands reflects the social realities our informants experienced.

While the field research allows me to foreground migrants' firsthand experiences that tend to be glossed over in the mainstream narratives about economic policy in national level, the spatial dimension of cross-border labor migration and the state's economic policy is not less crucial. should one hope to discern the intersection between these two phenomena. Therefore, in this article, I engage theoretically with spatial concepts from the discipline of geography to propose an alternative framework that accommodates both space and flow that are constitutive of each other.

\section{SEZs in the Southeast Asian context}

There are many terms used to describe geographically designated zones where firms can benefit from more relaxed laws and regulations as incentives for their investment. Those terms include, but not limited to, special economic zone, free trade zone, export-processing zone, enterprise zone, bonded warehouse, free port, maquiladora, etc. However, these nomenclatures share some common key characteristics and goals such as designated geographical areas for investment-- trade or manufacturing, or both; tax incentives; relaxed labor laws; pre-constructed facilities; attract investment to boost economic in either regional or national level.

Papadopoulos and Malhotra (2007) categorize the zones into two categories: zones that promote import or export activities; and zones that allow only trade or manufacturing. Therefore, in this sense, the term 'export-processing zone' might be more appropriate in the context of the international political economy in which the role of developing countries is emphasized and positioned in the global supply chain. In the meantime, special economic zone although sounds broader and more generalized highlights the state of exception in which the state executes its power. Either way, the development of the practice in the context of the global economy show both perspectives are the different sides of the same story: the emergence of powerful transnational or multinational companies (TNCS or MNCs) and the shift in their practice of global subcontracting (IBON Books, 2005).

SEZs in Southeast Asia, although locally situated within national boundaries, need to be contextualized in a regional economic cooperation entitled the Greater Mekong Subregion (GMS). Thame (2017) argues that SEZ has played a central role in the Greater Mekong Subregion Economic Cooperation Program (GMS-ECP) since the mid-1990s. Being established in 1992, GMS is a brainchild of Asian Development Bank (ADB) and is comprised of China and 5 Southeast Asian countries namely Cambodia, Lao PDR, Myanmar, Thailand, and Vietnam, all of which are the countries geographically linked together through the course of the Mekong River. This regional economic cooperation is designed as a mechanism to support the regional development through industrialization and regional economic integration. GMS, as an investment-promotion program is therefore connected to the global restructuring in subcontracting in the sense that GMS essentially seeks to establish favorable conditions for the private sector through multilateral investments in infrastructure, trade, and tourism across contiguous subregion (ibid).

Moreover, the goal of the ADB-led GMS also corresponds with the ASEAN economic plan to create a single market and production base in Southeast Asia broadly through the reduction of tariff

for the incredible support and constructive feedbacks from the two mentors: Dr. Jonathan Padwe (University of Hawai'i at Mānoa) and Dr. Ian Baird (University of Wisconsin-Madison).

${ }_{4}$ Crystal Maung, Spring Song, and Kzin Thuang Oo are graduates of the Children Development Center (CDC) School. 
barriers and the integration of Southeast Asian economy into the larger regional and global markets. As a result, a range of trade liberalization agreements has been formalized within the region. On the other hand, a significant amount of investment in infrastructure, including roads, railways, ports, bridges, power stations, high-voltage transmission lines, and telecommunications, resulted in a comprehensive infrastructure network called "Economic Corridors," connecting high economic potential cities across the region (ibid). SEZs have been built along these Economic Corridors to take advantage of their strategic location in the regional trade and investment network. Given that these Economic Corridors cut across the heartland of the member countries and connect cities with high economic potential together internationally as nodes in the network, the SEZs are therefore not necessarily located at the country's geographical borders.

\section{Thailand and Regional Labor Migration}

It is important to note that these regional economic development efforts in GMS are also embedded in the long histories of war and conflicts, which in turn had a significant impact on the path each Southeast Asian country has taken for its development goal. During the Cold War period, GMS countries were inevitably entangled with power struggle between the major powers. While Lao PDR and Vietnam were taken over by the communist parties, Myanmar closed its door and remained under the authoritarian regime for decades. In the meantime, Cambodia experienced a tragic political turmoil that resulted in the loss of million lives under the Khmer Rouge. Whereas its neighbors had encountered major obstacles, Thailand had a more stable political situation that led to a success in reaching UN's development goals in the late 1980 s.

Thailand unleashed its economic potentials by replacing its Import-substitute industry with export-oriented policy. The success in industrialization also resulted in economic growth, better living conditions and high rate of literacy among its population (Pearson and Kusakabe, 2012). This achievement consequently led to the two significant demographic trends afterwards (Paitoonpong and Chalaemwong, 2012). First, in the 1980s the emigration of Thai labor to work abroad for better payment tightened the domestic labor market. Second, migrant workers from neighboring countries where the economic disparity with Thailand was significantly high started to fill in the job vacancies. These migrants have become a fundamental driving force for the country's export-led manufacturing and other labor-intensive industries after since. However, while Thailand's economic growth depends a great deal on migrant labor, the Thai state has been caught in the dilemma between its national security and economic interest as the majority of migrant workers in Thailand is believed to be undocumented. Tang (2005) argues that undocumented migrant workers from Myanmar have emerged as a new class in Thai society since the 1990s.

Legality has become a twin issue of labor migration in Thailand as the most recent estimation of undocumented migrant workers in Thailand rose from 2-3 million in 2014 to 4-5 million in 2016 (IOM, 2017). Various social issues entangled around the politics of (il)legality of undocumented migrant workers. While the fear of the unknown led the nationalist to see undocumented migrant workers as a national threat and welfare burden, civil society advocates called for a better right protection mechanism for the workers who have suffered rights violation and exploitation by both business and state authorities. Since the 1990s, there has always been a series of legalization policy that tries to cope with the tension between economic demand for cheap labor and the national security. This constant stress manifested clearly in the spatial aspect of the legalization of undocumented migrant workers.

As mentioned previously, the presence of undocumented migrant workers in Thai society has been so prevailing since the 1990s. The migrant population have lived and worked across the country far beyond the border areas. But during this decade, the government policy regarding legalization was geographically limited: the workers were allowed to register and work only within the designated border province of registration. The geographical limitation continued until 2003 when the incumbent administration launched the first nationwide registration although the types of industries remained limited (Paitoonpong and Chalamwong, 2012, 44). In this sense, one can picture the way in which the Thai state gradually allowed the infusion of the migrant Other into its geo-body. However, the policy has yet to resolve the problem of illegal immigration as the government had expected. 


\section{Space and Flows}

The global economic restructuring in the 1980s led to major changes in the world economic and political systems. On the one hand, this economic restructuring led to the emergence of the global supply chain (Sassen, 1990). Free flow of capital challenged the conventional ideas about the state and its sovereignty. The rising trend of special economic zone implementation across the globe is a manifestation of this point (IBON Books, 2005). On the other hand, the global capitalism disposes people from their means of production, which led to the labor migration worldwide. These two trends are intrinsically connected; they contribute and perpetuate one another.

However, these two phenomena are often discussed in the two separate contexts. SEZ is discussed in the structural context where free flow of global capital and the state's control over "things" within its territory are in tension with one another. On the other hand, migrant figures emerged as a consequence of the dispossession form means of production by the global economic restructuring, and they are made vulnerable by the states' negligence. Scholars often theorize these migrants' experiences in the context of unequal power relations between the sovereign and its nonsubjects, through the Agambenian conception of bare life. Both approaches-the state-capital on the one hand, and migrant as bare life on the other, have different focuses, and therefore provide different yet relevant narratives. These two sides of the same story raise a question of how the two phenomena-SEZ implementation and labor migration in relations to the state, can be theorized as contributive to one another in the same scenario.

\subsection{Graduated Sovereignty}

Theorizing the interactions between the state and global economic forces through the economic liberalization policy, Ong (2000) proposes the concept of 'graduated sovereignty' to explore relationships and interactions between global corporations and non-market entities. In her classic piece "Graduated Sovereignty in South-East Asia," Ong, influenced by Michel Foucault's concepts of the modern governmentality and biopolitics, proposes the concept of graduated sovereignty as an analytical framework to understand the way in which modern state governs beyond the traditional means such as military and legal power. The modern state no longer simply employs supreme power over its populations. Rather, the state governs its population in several forms, all of which are integral to both state and society as Ong writes: "[s] tate management of the population [...]requires different modalities of government, based on mechanism of calculation, surveillance, control and regulation that set the terms, and are constitutive of a domain of social existence" (56).

Ong situates her Foucauldian conception in the context of the global economy where interactions between states, global markets, and transnational regulatory agencies, create new economic possibilities, and socio-political spaces. She argues that graduated sovereignty, or flexible modes of governing in my understanding, is a product of the interactions between state and globalization, and uses this model to describe two ways in which individual Southeast Asian countries have responded to the restructuring in global capitalism. First, the different ways in which state treats its population as the global market forces; second, the state-transnational network which is demonstrated in the practice of establishing SEZs.

Since Ong introduced the concept of 'graduated sovereignty' to the academia, multiple case studies of SEZs, especially in the Southeast Asian context, have shown the key features of state's graduated sovereignty-- differential treatments of citizens and transnational production network between states themselves, as well as transnational corporations. SEZs, usually accommodating export-oriented manufacturing industry, have been regarded as a spatial exception where the state allows exclusive treatments for global capitalism at the expense of their own national citizen. Nyiri (2012) discusses in the context of post-national world order. Following Ong, he starts with the acknowledgment that SEZ is the zone of exception where the state carved out some of the national territories, followed the profit-maximizing logic of neoliberal flexibility, but ultimately remained under the control of the nation-state elites (534). In the SEZ in Lao borderlands, Nyiri argues that post-national sovereignty is practiced. While both the Laotian, and the Chinese governments as the main facilitator of the SEZ investment and development, posses aspects of sovereign control over 
the territories and people working therein, much of the sovereignty is vested in a private corporation. This corporation, in turn, borrows the administrative and symbolic trappings of one and sometimes both states to bolster its own legitimacy.

\subsection{Migrant as Bare Life}

The global economic restructuring in recent decades has engendered an unquenchable demand for flexible migrant labor. On the contrary, the mobility of those who provide the highly demanded cheap labor is less likely to be embraced and more to be obstructed at, or even beyond the borders of the labor migration destination countries. Consequently, irregular migration has also become a global phenomenon alongside with the structural changes in the global economy. The experiences of social exclusion, labor exploitation, and rights violation, all of which have become a new normal for migrants, lead to political claims that test the limits of citizenship, the extension of political community and the expression of human rights (McNevin, 2007: 183).

Scholars from various disciplines have employed the concept of bare life by an Italian philosopher, Giorgio Aganben, to account for these migrants' experiences across the globe. Nair (2009) explains how the Malaysian state, one of the prominent labor migration destination in Southeast Asia, rendered migrant workers in its territory, bare life to serve the state's internal political purposes. The migrant others were the one to be blamed on for high unemployment rates among nationals, for fostering violent crimes, and for spreading contagious diseases (109). In the meantime, migrants suffered extremely low wages and poor working conditions, and without any access to rights protection.

Rajaram and Grundy-Warr (2004) also draw from Agamben's related concept of homo sacre and link this Roman-borne concept to a broader context of Southeast Asia and Australia. The authors use the case of Australia, Malaysia, and Thailand to portray how these states denied rights to irregular migrants who were subjected to the formers' jurisdiction. Although Rajaram and Grundywarr's main focus is the operation of detention centers or legal mechanism of the states that aim at coping with irregular migration to their territory, refugee and migrant-- two seemingly distinct categories of bare life, are portrayed as the subjects of the sovereign power.

The mixed basket of bare life in Rajaram and Grundy-warr, although vividly illustrates the different ways in which the state sovereignty renders irregular migrant lives vulnerable, I argue that the capitalist relationships between the state, market, and migrants themselves, is also made obscure. In this regard, I argue that the use of the concepts of graduated sovereignty for theorizing SEZs, and bare life for migrant workers, are the two sides of the same coin. They are intrinsically connected but often diverted into different courses of analysis. While SEZs as a spatial practice of the sovereign articulates the topographic approach, the state's project of making bare life is engaged with the topological approach to the borderland studies. Considering Thailand's border SEZs, I attempt to bring together these two foci--the state's spatial practice and its governmentality over migrant bodies, by discussing the concept of border partial citizenship.

\subsection{Border Partial Citizenship}

Pongsawat (2007) draws on Foucault's governmentality and politics of surveillance to discuss the identification card issuance as the Thai state's tool to declare one its subject, non-subject, and those who are included into the political discussion 'partially' as 'border partial citizens.' He discusses specifically the process of legalization in the 1990s in which the Thai government allowed Thai employers to bring in their undocumented migrant workers to register with the local authorities. Then, the workers would receive amnesty for their illegal entry to the country, thereby being eligible for temporary residency and work permit.

The partiality of citizenship right is expressed in the way that the issues of citizenship and immigrant were bypassed and rearticulated as a pure labor supply of production under the control of the state and the employer. During this time, the status granted to migrant workers after they came out of the shadow was not completely legalized immigrant. Rather it indicated the temporary status which was in waiting for deportation. The workers were required to reside only within the designated provinces where they registered, and not allowed to change the employer. This created 
a large pool of flexible labor power to supply the unquenchable demand for Thailand's export-led industry. Pongsawat argues that "it was the articulation of the political economic development in Thailand and the influx of illegal migration from Myanmar that led to the formulation of the new border partial citizenship regime" (189). He argues further that this border partial citizenship regime was also a building block for cross-border economic development as the regime created flexibility for the Thai state to control both its economy and the unauthorized human mobility within its territory.

The Thai state's policy which Pongsawat conceptualizes as the border partial citizenship later on was transformed to a seemingly more relaxing immigration law enforcement. This new legal practice although is different in detail from the legalization in the 1990s, still serves the purpose of the Thai state in dealing with the structural constraint between flows of capital investment and of cheap labor essential to maintaining the former within its territory.

\section{Border SEZs and the Formalization of an Economic Dam}

SEZs in GMS although are developed based on the concept of connectivity, there are two folds to be unpacked here. First, it encourages free flow of things and tourists, not all the laborers (Jones, 2016). Kudo and Ishida (2013) argue that cross-border development depends on a good balance between the divisiveness from the existence of the borders and the openness that allows movement of resources. Thailand's border SEZs plan exemplifies well this paradox as it is designed to take advantage of the disparity between Thailand and its neighboring countries.

SEZ has been part of the economic dream of the Thai state at least since 2004. The then Prime Minister Thaksin Shinawatra tried to push the bill about the land use for establishing the special economic zone. The practice of SEZ was believed to attract foreign direct investment to boost the Thai economy. But the bill did not pass through the parliament and fell short ever since. However, ten years after the bill was proposed by the Shinawatra civilian government, the idea was brought back to public attention again in 2014 by the military government led by General Prayut Chan-o-cha.

The military government exercised its nearly unchecked power through Article 44 of the 2014 interim constitution of Thailand. This controversial section gave the head of the National Council for Peace and Oeder (NCPO), the then governing body of the country, a power to release any order deem appropriate to suppress threats to national security, societal harmony, and the royal monarchy. Among many other things, the NCPO used this legal tool to expedite the plan to materialize border SEZs. The National Committee on Special Economic Zone Development (NC-SEZ) was founded as a mechanism to push forward the policy implementation. The NC-SEZ is comprised of the government agencies responsible directly to the infrastructures the Thai government promised to provide. These include necessary infrastructures, investment incentives, cross-border management of daily foreign workers, one-stop service centers, and other necessary activities. Although the implementation faced some resistance from local communities, the six pilot projects were pushed forward in the six border provinces namely Tak, Sa Kaeo, Trat, Mukdahan, Songkhla and Nong Khai.

A grand narrative that helped promote the SEZs project was the economic potential of the SEZ in ASEAN connectivity network and the upcoming ASEAN Economic Community (AEC). In a piece of the Thailand Board of Investment (BOI) promoting documents, the economic potential of the border SEZs lies in the cross-border connectivity between Thailand and its neighboring countries, as well as the economic opportunity from intraregional cooperation with AEC (Board of Investment (Thailand), 2015: 4). However, the Thai borderlands were not imagined naively as a bridge that facilitates transnational movement, at least for cross-border labor migration. Rather, the enforcement of Article 14 which will be discussed later, implies the border SEZ as an economic dam to funnel supplies, including labor supply, from neighboring countries while preventing the flow of migrant labors from flooding the inner part of the country. An official promoting document targeting foreign audience also stated clearly that the SEZs would help solve the problems of illegal immigration and smuggling of unauthorized produce from neighboring countries (Integrating with ASEAN and Connecting Thailand to the Global Community, Royal Thai Embassy, 2017).

However, when considering the trends in legalization since the 1990s, the new law signified a change in the position of the Thai state signaling an attempt, as Popescu (2012) argues, to remain 
relevant in the changing socioeconomic landscape of the twenty-first century. The implementation of Article 14 shows a form of reterritorialization of the Thai state's geo-body. Up to the enforcement of Article 14, the policy toward undocumented migrant workers in Thailand is mostly in ad hoc and "defensive" manner as the government had launched rounds and rounds of registration and amnesty for illegal immigrants who already crossed the border and were residing in Thailand. In the meantime, the cumbersome and costly government-to-government labor import scheme has evidently resulted in a very low number of participants. Not to mention that the migrants who migrated to Thailand through this government-to-government channel were still documented facing right violation and mistreatment by the government authorities (MoU system still exploits workers, Bangkok Post, 2016). Crossing the porous borders is still easier and more affordable.

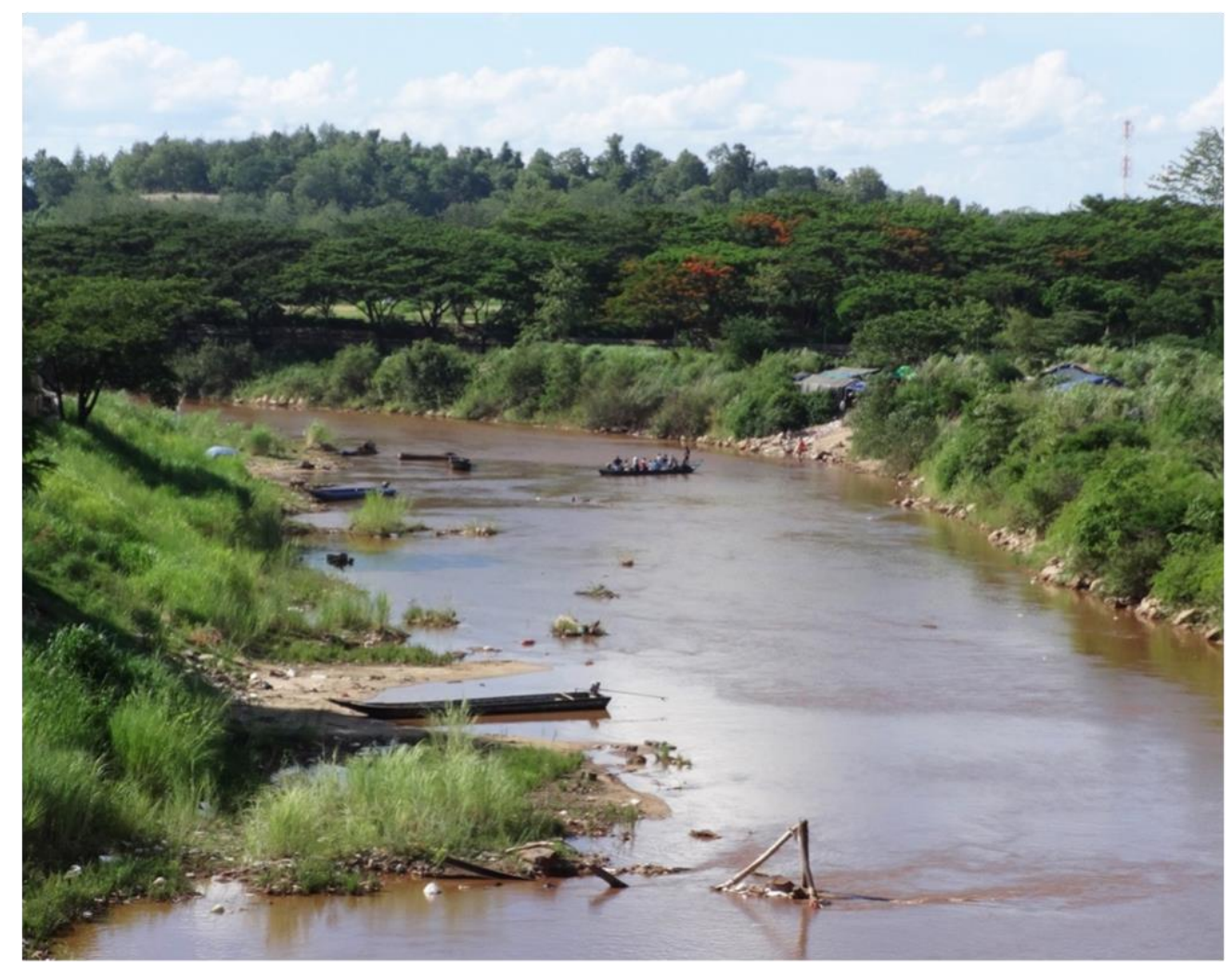

Figure 1: Porous border enables border crossing without the state's authorization. In the photo, borderland people are crossing the Moei River, the international border line between Thailand and Myanmar. The Photo was taken by the author from the Thai-Myanmar Friendship Bridge where the official border pass is located.

The Thai state might have eventually come to understand this nature of the border, and implemented Article 14, which I argue here as a form of reterritorialization. Initially, Article 14 started only for seasonal migrant worker employment, particularly in agricultural industry where the cheap labor is needed most during harvest season. Later on, along the way the idea of SEZ has been developed and pushed forward, business stakeholders from the industrial sector advocated stretching the limit off (personal Interview, 2015). As of January 2018, the validation period of seasonal worker entry was extended to with 90 days/entry to accommodate manufacturing industry along the borders (Seasonal Alien Workers, National Broadcasting Services of Thailand, 2017).

In short, Article 14 loosens up the immigration protocol for immigrant workers from the neighboring countries that share contiguous borders with Thailand. The workers could use border pass issued in local administrative office, instead of passport or certificate of identity, which usually takes a longer time to be issued with higher cost compared to border pass. The immigrants can cross the border to Thailand, apply for work permit, and take a medical check-up. However, the registering process still requires that the immigrants register with their employers and they will be required to stay only within the designated border areas only. On the one hand, this practice signified a change 
from borderlines, to borderlands, a zone where traditional relationships between the sovereign and flow of migrants are reorganized.

While it seems increasingly relaxing, this happens concurrently with a stronger push to legalize undocumented workers already living in Thailand through the intensification of legalization of undocumented migrant workers in the inner parts of the country. On the one hand, the Thai government tried to funnel undocumented migrant workers who already reside in Thailand to go through the national verification process and/or push them to leave the country and re-enter again through the government-to-government MOU process.

\section{Thailand 4.0 and the Sanitization of the Thai Geo-Body}

In the late 2016, the Thai government introduced "Thailand 4.0," a new economic vision to the Thai society. Thailand 4.0, as a holistic approach to development, aims at escaping the middleincome trap caused by the previous development policy which focused on rudimental agricultural production (Thailand 1.0), light industry (2.0), and advanced industry (3.0). A goal of the model is to reach at 4.0 level or knowledge-based economy, which is driven by high-valued technology. The vision not only focuses on the new paradigm of national economic development, but also addresses social and environmental challenges in the twenty-first century. As stated on the website of the Royal Thai Embassy in Washington, D.C., Thailand 4.0 will also "create a society that moves forward without leaving anyone behind...through the realization of the full potential of all members of society....[and] become a livable society that possesses an economic system capable of adjusting to climate change and low carbon society" (Thailand 4.0, Royal Thai Embassy, 2017a).

The Thailand 4.0 model aims at shifting from labor-intensive and rudimentary technology industries to the value-based and innovation-driven economy through a significant investment in technology and research development. Regarding technological transition, the Thai government launched the " $5+5$ Superclusters Scheme"; the first promoted five industries will be build up on the traditional economic strength namely Next Generation Automotive, Smart Electronics, Affluent, Medical and Wellness Tourism, Agricultural and Biotechnology, Food for the Future. Also, the other five groups are newly promoted industries with the main goal to enhance the country's capabilities and to shift from its comparative advantage to competitive advantage. The latter group consists of Robotics, Aviation and Logistics, Biofuels \& Biochemical, Digital, Medical Hub (Development of Technology Cluster and Future Industries, Royal Thai embassy, 2017b).

While the narrative about economic development model changed from export-oriented industry to value-based economy, the emphasis on the border SEZs was also replaced with the Eastern Economic Corridor (EEC), a new vision for the high-value industrial zone. Although EEC was also positioned as a special economic zone, it is not designed to accommodate export-oriented, labor-intensive industry like its other counterparts along the borders. EEC is to be built up on the existing facilities of the oil refinery and automobile parts in the Eastern Seaboard industrial zone, located on the country's eastern coast area in 3 provinces namely Chachoengsao, Chonburi, and Rayong.

The positioning of EEC corresponds with the larger narratives about the goals of Thailand 4.0 and how Thai nationhood was mobilized to unite divisive Thai society. A variety of knowledge-based economy buzz words were infused with sufficiency economy philosophy, introduced and popularized by the late King Bhumibol Adulyadej, ${ }^{5}$ who emphasizes on moderation and balance (Public Relation Department, 2016). Through these nationalist discourses, every entity of the Thai society is begged to play their part and contribute to the sustainable development of the country. It

\footnotetext{
5 The late King Bhumibhol Adulyadej was the ninth monarch of Thailand from the Chakri dynasty. Upon his death in October 2016, the much revered King was the longest-serving monarch who ruled for 70 years . During his reign, the King has become the center of the Thai society through his nationwide royal development projects that aim at eliminating poverty among his subjects, as well as his interventions in the political crises throughout Thailand's contemporary political history. At a ceremony of the $60^{\text {th }}$ anniversary of his ascent to the throne in June 2006, the King received the United Nations' first Human Development Lifetime Achievement Award presented to him by the then UN Secretary-General Kofi Annan.
} 
is an attempt by which the military government use to legitimate its ruling power as a savior to unite the country that has been politically divided for the past decade.

While the country's dream-like vision is moving toward the high-valued economy, the plan to establish labor-intensive border SEZs becomes a stale bread. Again, in the website of the Royal Thai Embassy in Washington D.C., the Border SEZs is mentioned briefly with only a sentence hidden in Agenda Five about ASEAN regional connectivity, written: "[SEZs] will improve economic opportunities and competitiveness, attract investment both domestic and international while simultaneously regulate the border economic areas to resolve issues such as illegal migrant workers and the trafficking of agricultural products from neighboring countries" (Integrating with ASEAN and Connecting Thailand to the Global Community, Royal Thai Embassy, 2017c).

The geographical areas of these 4.0 technology clusters are unclear. But in principle, it is supposed to be linked together through logistics infrastructure of supply chains, which corresponds with the GMS model of regional development. The plan is to upgrade the existing industries to a more advanced technology-based one while the labor-intensive manufacturing industry is for the border areas. In this sense, the border is othering through the Thai state's economic cosmology of technology evolution. Outside the border zones, the legalization of the undocumented migrant workers has been high on agenda. The Thai state hopes to make legible (Scott, 1999) the immigrants whose lack of record has engendered the fear of the unknown. While the border seems opening, the inner core of the Thai geo-body is hyper-securitized.

In June 2017, the Thai government passed a new Royal Decree in Migrant Labor Management B.E. 2561 (2018) to tackle the problem of irregular labor migration to the Kingdom. The new provides the guidelines for migrant worker employment and the types of work that migrant workers are allowed to take, as the previously revoked Alien Employment Act (2008) did. However, the different is that the new Decree has a novel aim at addressing the problem of both illegal migration and human trafficking. It increases the penalty for both employers and workers who violate the laws, and provides some specific guideline to protect Victim of Trafficking and to persecute those traffickers. The aspect relevant to illegal employment tremendously impacted the Thai business and industries across the board. The fear of severe punishment, i.e. exorbitant fine and imprisonment, led to an abrupt layoff from the employer side and the exodus of migrant workers who abandoned the jobs and returned their home across the borders. To mitigate the situation, the government inevitably postponed the enforcement to the end of June 2018 in hopes of granting enough transition period for both business communities and the workers for legalization process.

In essence, the Thai State is sanitizing the inner core of the country while letting its periphery to be a buffer zone where both capital and labor can be circulated and exploited without disrupting "Thailand Proper." Although the government acknowledges the issue of human trafficking and attempts to revise the law to address such problems, legality and legalization of migrant workers remain central to the public discourses and government policy.

\section{The Geo-Body Enclosure and Peoples in the Borderland}

In January 2018, H.E. Police General Adul Sangsingkeo, Thailand's Minister of Labor urged employers and migrant workers not to delay their application to avoid missing the deadline in June 2018 and become illegal and subject to the new decree ("รมต แรงงานสั่งเร่ง." [Minister of Labor Urges.]. ThaiPBS, 2018). This extended period is meant to provide 'enough' time for the government agents, as well as roughly one million workers whose applications have already been in the system, to finish the ongoing national verification. Civil society advocating for migrant worker rights voiced a concern toward the bureaucratic and corruptive legalization that could do more harm than good to the workers. The Migrant Rights Promotion Working Group (MRPWG) reported some broker company agents, as they claimed, were lying in wait for migrant workers in front of the One-Stop Service Center in Mae Sot and tried to funnel the migrant workers to their legalizing services instead of entering the Center. Despite the government's effort to regulate the abusive broker companies, the MRPWG's statistic revealed that in every month throughout the year 2017, there were at least five cases in which migrant workers in Mae Sot were hindered from processing their status adjustment due to such broker incident ("เครือข่ายส่งเสริม." [Network of.]. Prachatai, 2018). This report not only shows the negative side-effects of legalization, but also the potential of corruptive 
system. More importantly, the estimation of one million workers mentioned in the media, is only the number of those who had already started their legalizing process whereas the estimated of undocumented migrant workers in Thailand has never become clear to either the government agencies or civil society. It is very likely that there remains a large group of migrant population who have never been involved in any kind of registration. These people, as well as the new comers, are not counted in the current narrative. Thus, by July 2018, we can still expect a number of migrant workers in the country who are even more at risk of being punished by exorbitant fine, deportation if not reverse effects of underground exploitation.

Since the coup d'état in May 2014, the Thai geo-body sanitizing has clearly become a cyclical pattern. The government claimed national security interest and implemented a rigid policy on illegal migrant workers in the country. People got panic. Then business is effected and the government need to loosen up its policy again. As of January 2018, the new rigid Decree implementation has been put off twice since its first enforcement in June 2017. Although the history seems to repeat itself, this time, one thing that looms large in the process, is the leverage of voluntary deportation as part of the public discourses on legalization. Deportation, voluntary or not, becomes more pervasive in the Thai public media as the government tries to forge return of illegal migrants to their countries of origin and reenter Thailand through the government-to-government MOU channel if not going through the national verification process. Like other times since the beginning of registration in 1992, the Thai government reiterated that there will no longer be the next round of registration for illegal migrants inside the country: migrant workers need to go through either the national verification process or the MOU channel. Those who fail to be legalized through these processes will be subject to legal punishment and deportation. Although the deportation is not a new practice for the Thai state (cf. Human Right Watch, 2012) this time, it has become more worrying due to the political and economic contexts in which the deportation signifies the resource enclosure (Jones, 2016; 2012). The Thai border regime was systematically designed to keep lowskilled migrant workers out of the heartland of knowledge-based economic prosperity, thereby costing the migrants more expensive and dangerous voyage to a better economic opportunity.

During the past four years from 2014-2017, I have conducted multiple interviews with two representatives from the Yaung Chi Oo, a Community-Based Organization (CBO), who has been the front line of migrant worker rights in Mae Sot. As far as the staff's first-hand experiences along the Thai-Burmese borders are concerned, their opinion regarding the situations of labor migration form Myanmar to Thailand and migrant worker rights protection mechanism, remain the same despite the drastic political and economic changes at the centers of both Myanmar and Thailand. Migrants will continue crossing the border to Thailand mainly because of the better economic opportunity in Thailand. The Yaung Chi Oo's borderland perspective corresponds to the situations of Hlaing Tharyar SEZ workers in Yangon covered by the Myanmar Times (2017), which shows that workers in the industrial zones still earned significantly less than their counterparts on the Thai side of the border. On the other hand, my ethnographic data shows that local business in the border areas have suffered labor shortage since the dawn of democratization of Myanmar in 2011. The border economic regime that builds on the suppress of migrant labor wage is therefore self-destructive as the workers tried to seek opportunity to flee the extremely low wage to a more sustainable payment in the inner part of Thailand. In an interview, a business person even likened Mae Sot to an apprentice town where migrant workers crossed the border to attain some occupational and language skills and move away to the Thai inner cities for better-paid job, with their better skills.

The SEZ and AEC hype, that tried to promote cross border economic activities, have engendered a significant transformation of the Thai-Burmese borderlands. Land price speculation was so inflating. Advertisements for land sale, property renting, or even temporary housing catering for business persons and middle-class tourists were not uncommon along the main roads in town More new infrastructures. The borderland has changed and become more urbanized with the labor of migrant workers. There are more condominiums, life-style shopping malls, and neighborhood gentrification, all of which were materialized with migrant labor power. But once, the space was transformed, the presence of migrant became absent from the border landscape. They were desired to be part of this border prosperity narrative again as consumers crossing the border to consume 
modernity and development, which has not yet existed on the Myanmar, but Thai sides. The Ads in Burmese scripts tell it all.

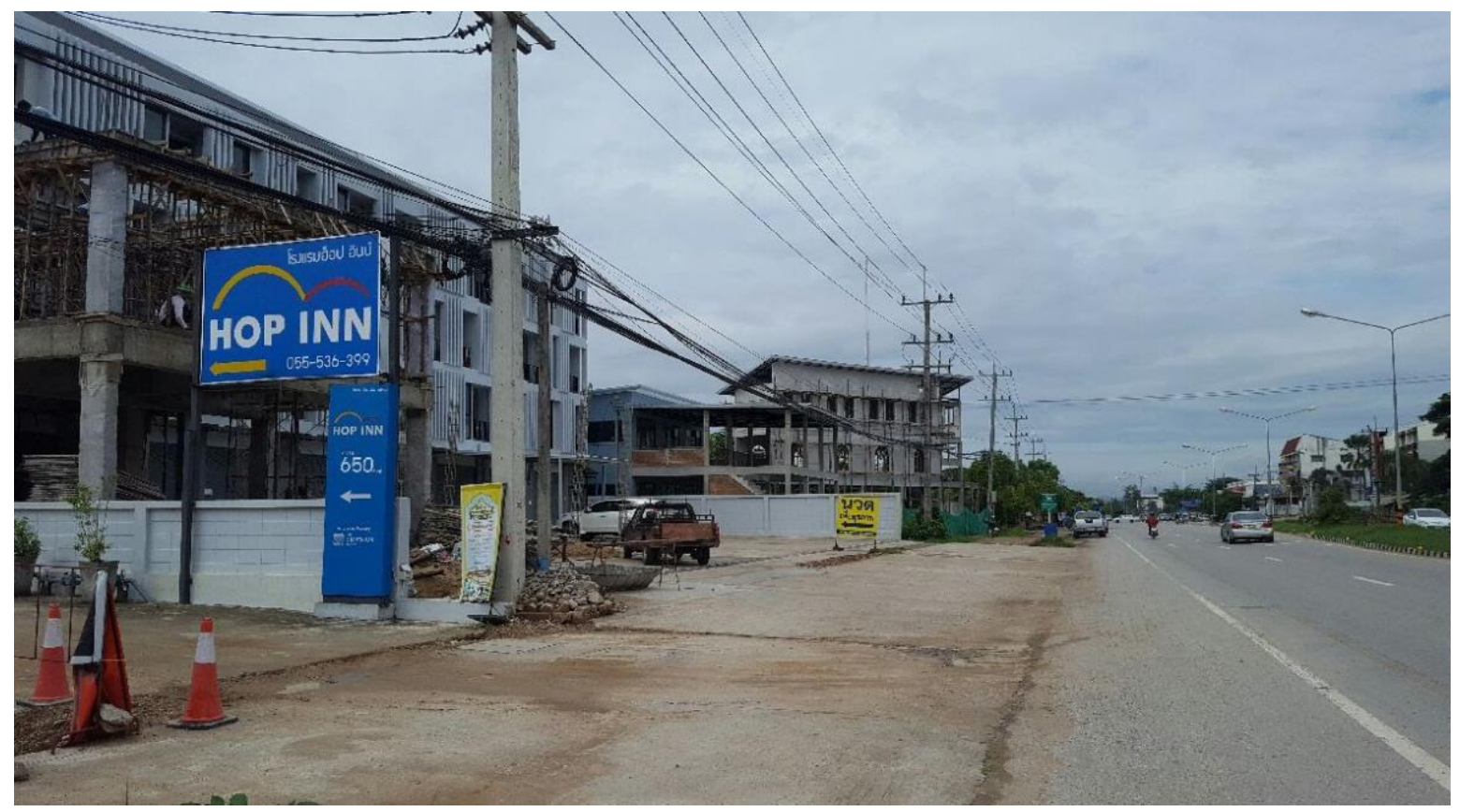

Figure 2: After the announcement border SEZ, various forms of property development sprung up in Mae Sot and its vicinity. In this photo, an affordable hotel targeting short-term visitors and fews commercial buildings were newly built along the Asian Highway Road toward the permanent border pass at the Thai-Myanmar Friendship Bridge. Photo by the author.

\section{Conclusion}

This paper uses the Thai state's spatial practice envisioned through its economic development plan to explore the political imagination about the Thai geo-body. The analysis is delivered through the lens of the central-peripheral spatial relationship. It shows how the Thai state responded to the structural change in the global economic restructuring that resulted in transnational flows of things and people, which in turn pose a challenge to the conventional ideas of state sovereignty over its territory. The Thai state reterritorialized its borderlands by endorsing the implementation of Article 14 of the Alien Employment Act (2008), a more relaxed immigration law to maintain supply of cheap labor from its neighboring countries to feed its export-led industrial sector. In another layer, the reorganized social relationships between the sovereign and its non-subjects does not mean a lesser degree of bordering by othering (Joseph and Rothfuss, 2014) as the government hardened its policy on undocumented migrant worker legalization and encouraged the government-to-government labor import scheme which is cost-prohibitive to many migrants. These moves, at the end, portray the vision of exclusive prosperity within a national boundary. While the Thai state proceeds to position its national geo-body as an accommodating space for the appealing transnational flows of capital and high-valued technology, an important question underlining this move also looms large: how the rhetoric of sustainable development and economic prosperity could be materialized with a discriminating policy that is based on the simplified and fragile dichotomy between the inside and outside of the border?

\section{Appendix A: List of Acronyms}

ASEAN Association of Southeast Asian Nations

AEC ASEAN Economic Community

ADB Asian Development Bank

Article $14 \quad$ Article 14 in the Alien Employment Act B.E.2551 (2008) 


$\begin{array}{ll}\text { BOI } & \text { Board of Investment (of Thailand) } \\ \text { CBO } & \text { Community-Based Organization } \\ \text { EEC } & \text { Eastern Economic Corridor } \\ \text { GMS } & \text { Greater Mekong Subregion } \\ \text { GMS-ECP } & \text { Greater Mekong Subregion Economic Cooperation Program } \\ \text { MNCS } & \text { Multinational Companies } \\ \text { MOU } & \text { Memorandum of Understanding } \\ \text { MRPWG } & \text { Migrant Rights Promotion Working Group } \\ \text { NCPO } & \text { National Council for Peace and Order } \\ \text { NC-SEZ } & \text { National Committee on Special Economic Zone Development } \\ \text { SEZ } & \text { Special Economic Zone } \\ \text { TNCS } & \text { Transnational Companies } \\ \text { UN } & \text { United Nations }\end{array}$

\section{Acknowledgement}

I am thankful for the two anonymous reviewers for their thoughtful comments, and Dr. Reece Jones who commented on the very first draft of this article in his Political Geography course at University of Hawai'i at Mānoa.

\section{References}

Board of Investment (Thailand). (2015). Guide to Investment in the Special Economic Development Zones.

Hall, A. (2016, April 8th). MoU system still exploits workers. Bangkok Post. Retrieved from https://www.bangkokpost.com/opinion/opinion/925649/mou-system-still-exploits-workers

IBON Books. (2005). Export Processing Zones: A Path Towards Industrialization? (IBON Issue Primer Series). the Philippines.

International Organization for Migration (IOM). (2017). IOM Thailand National Strategy 2017-2020.

Jones, R. (2012). Border Walls: Security and the War on Terror in the United States, India, and Israel (1st ed.). London \& New York: Zed Books.

Jones, R. (2016). Violent Borders: Refugees and the Right to Move. London \& New York: Verso.

Joseph, Y., \& Rothfuss, R. (2014). Symbolic Bordering and the Securitization of Identity Markers in Nigeria's Ethno-Religious Segregated City of Jos. In Placing the Border in Everyday Life. London\&New York: Routledge.

Kudo, T., \& Ishida, M. (2013). Prologue: Progress in Cross-Border Movement and the Development of Border Economic Zones. In Border Economies in the Greater Mekong Sub-region. Palgrave Macmillan.

MCNEVIN, A. (2007). Irregular migrants, neoliberal geographies and spatial frontiers of "the political." Review of International Studies, 33(4), 655-674. https://doi.org/10.1017/S0260210507007711

Nair, S. (2009). Sovereignty, security, and migrants: Making bare life. In International Relations and States of Exception: Margins, peripheries, and excluded bodies (pp. 95-115). London\&New York: Routledge.

Nyiri, Pal (2012) "Enclaves of Improvement: Sovereignty and Developmentalism in the Special Zones of the China-Lao Borderlands." Comparative Studies in Society and History. 54(3) 533-562.

Ong, A. (2000). Graduated Sovereignty in South-East Asia. Theory, Culture \& Society, 17(4), 55-75. https://doi.org/10.1177/02632760022051310

Paitoonpong, S., \& Chalamwong, Y. (2012). Managing International Labor Migration in ASEAN: A Case Study of Thailand. Bangkok, Thailand: Thailand Development Research Institute.

Papadopoulos, N., \& Malhotra, S. (2007). Export Processing Zones in Development and International Marketing: An Integrative Review and Research Agenda. Journal of Macromarketing, 27(2), 148-161. https://doi.org/10.1177/0276146707300070

Pearson, R., \& Kusakabe, K. (2012). Thailand's Hidden Workforce: Burmese Migrant Women Factory Workers. London\&New York: Zed Books. 
Popescu, G. (2011). Bordering and Ordering the Twenty-first Century: Understanding Borders. Rowman \& Littlefield.

National Broadcasting Services of Thailand. (2017). "Seasonal Alien Worker." Retrieved from: https://www.youtube.com/watch?v=r49ApRFp3xg

Pongsawat, P. (2007). Border Partial Citizenship, Border Towns, and Thai-Myanmar Cross-Border Development: Case Studies at the Thai Border Towns (Dissertation). University of California, Berkeley, Berkeley.

Public Relation Department. (2016, October 31). Transition toward Thailand 4.0 through the Sufficiency Economy Philosophy. Inside Thailand. Retrieved from http://thailand.prd.go.th/thailand/ewt_news.php?nid=4083\&filename=index

Rajaram, P. K., \& Grundy-Warr, C. (2004). The Irregular Migrant as Homo Sacer: Migration and Detention in Australia, Malaysia, and Thailand. International Migration, 42(1), 33-64. https://doi.org/10.1111/j.0020-7985.2004.00273.x

Royal Thai Embassy, (2017a) "Thailand 4.0." [website]. Retrieved from: http://thaiembdc.org/thailand-4-0-2/ Washington DC.

Royal Thai Embassy, (2017b) "Development of Technology Cluster and Future Industries." [website]. Retrieved from: http://thaiembdc.org/agenda-2-development-of-technology-cluster-andfuture-industries/ Washington DC.

Royal Thai Embassy, (2017c) "Integrating with ASEAN and Connecting Thailand to the Global Community." [website]. Retrieved from: http://thaiembdc.org/agenda-5-integrating-withasean-and-connecting-thailand-to-the-global-community/ Washington DC.

Scott, J. C. (1999). Seeing Like a State: How Certain Schemes to Improve the Human Condition Have Failed. Yale University Press.

Sassen, S. (1990). The Mobility of Labor and Capital: A Study in International Investment and Labor Flow (Paperback). Cambridge: Cambridge University Press.

Tang, L. L. (2005). Statelessness, human rights and gender : irregular migrant workers from Burma in Thailand. Brill Academic.i

Thame, C. (2017). SEZs and Value Extraction from the Mekong: A Case Study on the Control and Exploitation of Land and Labour in Cambodia and Myanmar's Special Economic Zones. Bangkok, Thailand: Focus on the Global South.

Winichakul, T. (1994). Siam Mapped: A History of the Geo-Body of a Nation. Honolulu: University of Hawaii Press.

เครือข่ายส่งเสริมสิทธิแรงงานข้ามชาติที่แม่สอดเรียกร้องการจ้างงานเป็นธรรม [Network of Mae Sotbased Migrant Rights Advocate Calls for Just Employment]. (2017, December 17). Prachatai. Retrieved from https://prachatai.com/journal/2017/12/74628

รมว.แรงงานสั่งเร่งพิสูจน์สัญชาติแรงงานต่างด้าว พบยังไม่ขึ้นทะเบียนอีก 8 แสนคน [Minister of Labor Urges the National Verification Process. 8 Hundred Thousand Found Unregistered]. (2018, January 12). ThaiPBS. Retrieved from https://news.thaipbs.or.th/content/269297 